\title{
STATCOM BASED ON MODULAR MULTILEVEL CONVERTER: DYNAMIC PERFORMANCE AND TRANSIENT RESPONSE DURING AC NETWORK DISTURBANCES
}

\author{
G.P. Adam, Giddani O. Anaya-Lara and G. Burt \\ University of Strathclyde \\ Email:grain.adam@eee,strath.ac.ukandolimpo.anaya-lara@eee.strath.ac.uk
}

Keywords: Fault ride-through capability, flexible ac transmission systems, modular multilevel converter, and static synchronous shunt compensator.

\begin{abstract}
This paper presents detailed assessment of the behaviour of STATCOM based on modular multilevel converter during steady-state and transient operation. The steady-state performance of the presented STATCOM is examined when it provides autonomous voltage regulation across number of switch loads. Its transient response is examined by subjecting the test system where STATCOM is connected to symmetrical and asymmetrical ac network faults. In this work, STATCOM power circuit is modelled using detailed switch model of modular converter with 16 cells per arm, including capacitor voltage balancing strategy, and control systems are represented detail (dc and ac voltage regulars, and current controller). Simulations conducted in MatlabSimulink enlivenment are used to assess the STATCOM performance.
\end{abstract}

\section{Introduction}

Increased focus on exploitations of renewable energy resources for electricity generations worldwide may lead to significant changes to the way the power systems operate and respond to network disturbances. These changes may be exacerbated in the power system networks with high penetration of non-dispatchable renewable power generations and reduced level of conventional generations, as such network experience continuously active and reactive power mismatch due to the intermittent nature of renewable energy resources such as wind and solar. These may cause increased risk of frequency and voltage instability and other power quality issues such as flickers and voltage swell.

Flexible AC transmission systems (FACTS) devices can be used to improve active and reactive power flow in the ac networks in order to increase utilization of existing ac lines, assist renewable power generations to comply with the grid codes, and address of the power quality issues aforementioned[1-3].

Despite the voltage source converter based FACTS devices are superior to that based line commutated thyristor in terms of performance and dynamic response their used remain limited in today AC power systems[4-6]. This is due to increased concerns regarding their reliability during harsh grid conditions and losses they may introduced. Recent increases in the power rating of renewable power plants necessitate the use of large FACTS devices that are applicable to high-voltage and capable of withstanding different ac network disturbances. Adoption of voltage source multilevel converters in FACTS devices increase their operating voltage and power rating to the level comparative to that based on thyristor. They offer additional benefits to ac networks such as dynamic voltage/or reactive power support for large onshore/or offshore wind farms, and reduced harmonic emission $[6,7]$. The use of pulse with modulation allows the FACTS devices based voltage source converter to mitigate flickers and actively attenuate low order harmonics existing in the ac networks, and they can be combined with battery storage systems to provide load levelling, frequency support and synthetic inertia to ac networks. At the present voltage source modular multilevel converter is adopted to FACTS devices[1, 5, 8-11]. However, its power circuit and control systems complexity raises many concerns regarding its ability to withstand network faults.

In attempt to address some of these concerns regarding the reliability of the modular converter, this paper chooses a static synchronous compensator (STATCOM) based on 17-level modular converter as an example of modern high-voltage high-power FACTS devices, to investigates its dynamic performance and transient response during ac network faults. In this investigation, a detailed model of STATCOM based on modular multilevel converter with 16 cells per arms will be used, with all controllers are incorporated. The test system in Fig. 1, where a STATCOM is attached at the middle of the line connecting two ac networks will be used to demonstrate its ability to withstand ac network disturbance.

\section{Modular multilevel converter}

Fig. 1a shows one-phase leg of generalized modular converter with $N$ cells per arm, and it can generate $N+1$ voltage levels per phase. Despite Fig. 1a shows modular converter with twoswitch cells and H-bridge cell, this paper only discusses the version with two-switch cells. Each converter arm must be able to support the full dc link voltage; this may significantly increase the converter footprint. Proper converter operation 
requires voltage across each cell capacitor must be maintained at $\frac{1}{N} V_{d c}$, where $\mathrm{V}_{\mathrm{dc}}$ is the dc link voltage. Each semiconductor switch experiences a maximum voltage stress limited to one capacitor voltage. The arm inductance $L_{d c}$ is normally sized to limit potential inrush current during capacitor voltage balancing processing and circulating currents between the phases during unbalanced operation. In addition, it acts as a low pass filter, contributing to the improvement of the phase current quality. Some of the distinct features of the two-switch $\mathrm{M} 2 \mathrm{C}$ are[9]:

a) Unlike diode clamped and flying capacitor multilevel converters, M2C can be extended to high number of levels without capacitor voltage balancing problem; this permits elimination of ac filters and interface reactors.

b) Can operate over full modulation index linear range (0 1.15), independent of load power factor.

c) Converter switching devices operate at small voltage steps and low switching frequency; this may result in low conversion losses (dominantly on-state losses), and machine windings may experience low $d v / d t$.

Modular multilevel converter with large number of cells can be operated using pulse width modulation or amplitude (or staircase) modulation. However, in this paper amplitude modulation is favoured over pulse width modulation approach due to simplicity of implementation and potential elimination of unnecessary switching actions that may result in addition switching losses. Modulation strategy adopted in this paper does not allow switching between two voltage levels more than one time per quarter of fundamental period. Voltage balance of the cell capacitors in each converter arm is maintained by selecting appropriate number cells in order to track the upper and lower arm voltage waveforms $\frac{1}{2} V_{d c}(1-M \sin \omega t)$ and $\frac{1}{2} V_{d c}(1+M \sin \omega t), \quad$ taking into consideration capacitor voltage magnitudes and phase (or arm) currents polarities[5, 9].
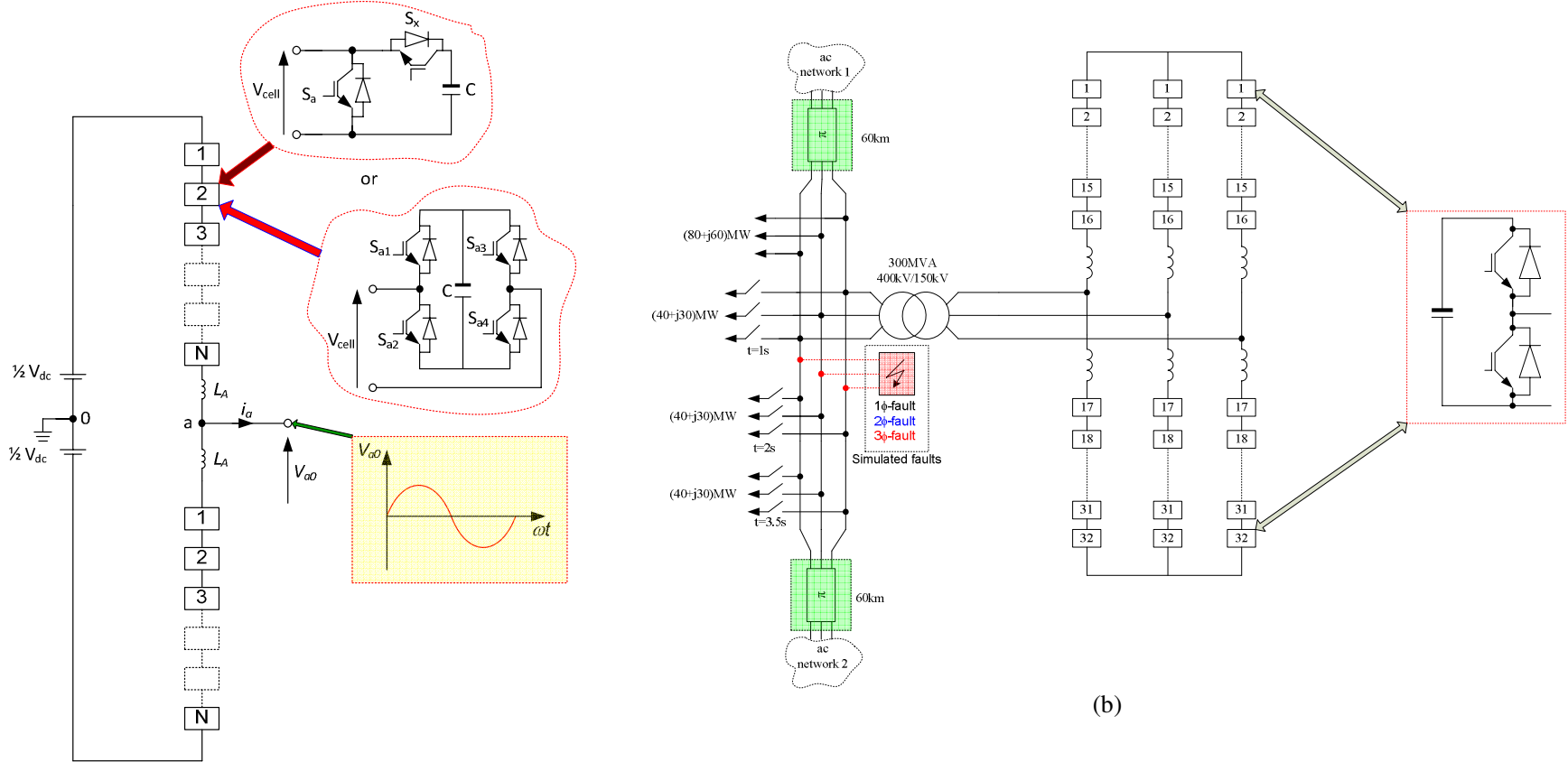

(b)

(a)

Fig. 1:(a) One-phase leg of modular converter with $\mathrm{N}$ cells per arm and (b) Test system

\section{Test system}

Fig. 1b shows the test system, where a 300MVA M2C based STATCOM with no common de link capacitor is connected across a group of switch loads through a 300MVA $150 \mathrm{kV} / 400 \mathrm{kV}$ transformer (no common dc link capacitors means no risk of dc side fault). No interfacing reactors and ac filters are used. Capacitance used within each cell of the M2C is $6 \mathrm{mF}$. In order to extend the modulation index linear range required for generation of leading reactive power, sinusoidal with triplen harmonics injection references are adopted. To limit potential circulating currents between the phases and inrush currents during voltage balancing of the cell capacitors, arm inductances of $10 \mathrm{mH}$ are incorporated. The ac networks 1 and 2 are rated at $400 \mathrm{kV}, 10000 \mathrm{MVA}$ with $X / R=5$. The STATCOM dc voltage regulator maintains the $\mathrm{dc}$ link at $300 \mathrm{kV}$. In order to prevent large voltage dips across the switch loads, the STATCOM is operated in a voltage support mode where the ac voltage controller constantly attempts to maintain the voltage magnitude at point of coupling at $1.0 \mathrm{pu}(400 \mathrm{kV})$. The system is subjected to symmetrical and asymmetrical ac faults at the location in Fig. $1 \mathrm{~b}$ to examine the transient performance of the M2C based STATCOM during ac network faults.

\section{Simulations}

To demonstrate the viability of the modular multilevel converter STATCOM in high-voltage power systems, the test system in Fig. 1b is simulated in the Matlab-Simulink environment, with parameters given in section 3. Fig. 2 shows the results obtained when three loads of $(40+\mathrm{j} 30)$ MVA are connected at times $\mathrm{t}=1 \mathrm{~s}, \mathrm{t}=2 \mathrm{~s}$ and $\mathrm{t}=3.5 \mathrm{~s}$. Fig. $2 \mathrm{a}$ shows the 
line voltage at the converter terminal (before the converter transformer). It can be observed that the modular multilevel converter produces high quality sinusoidal line voltages with extremely low $d v / d t$ and low harmonic content presented to the converter transformer. This results shows that no ac filter is necessary at connection point as transformer leakage inductances are sufficient to attenuate switching frequency components in the converter output voltage (this may reduce STATCOM footprint). Low $d v / d t$, as demonstrated in Fig. 2a, eliminates the need for a converter transformer with high insulation, which reduces STATCOM cost. Fig. $2 b$ shows the voltage waveforms across the switch loads at point of common coupling. Fig. 2c shows the current waveforms the STATCOM injects into ac network at the point of common coupling. Figs. $2 \mathrm{~b}$ and $2 \mathrm{c}$ demonstrate the ability of the presented solution to comply with any harmonic requirements without additional cost or need to increase converter switching frequency. Figs. $2 \mathrm{~d}$ and $2 \mathrm{e}$ show the voltage magnitude across the switch load, and active and reactive power STATCOM exchanges with the ac network. The STATCOM maintains the voltage across the switch load at $1.0 \mathrm{pu}(400 \mathrm{kV})$ by adjusting its reactive power exchange with the ac network. The red dash line in Fig. 2e shows the active power STATCOM absorbs to maintain its de link voltage and compensates for its losses, which are minimal. This power may increase slightly if a full converter loss model were to be included in the simulation. Waveforms in Fig. 2f show STATCOM arm current contain some even harmonics, but no dc offset as that in real power applications, such as that in HVDC transmission systems. This means in such applications STATCOM based on modular converter may exhibit low conversion losses. The voltage balance of the STATCOM cell capacitors is maintained at $300 \mathrm{kV} / 16(18.75 \mathrm{kV})$ as its reactive power exchange with the grid varies. This means the voltage stresses across converter switches are maintained under controlled.

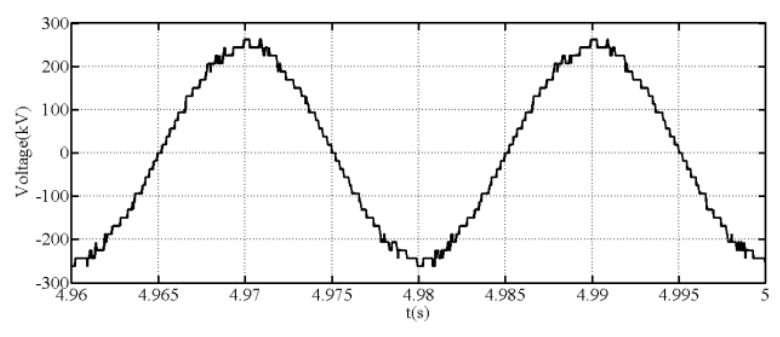

a) Line voltage waveform converter presents to interfacing transformer (Converter terminal voltage)

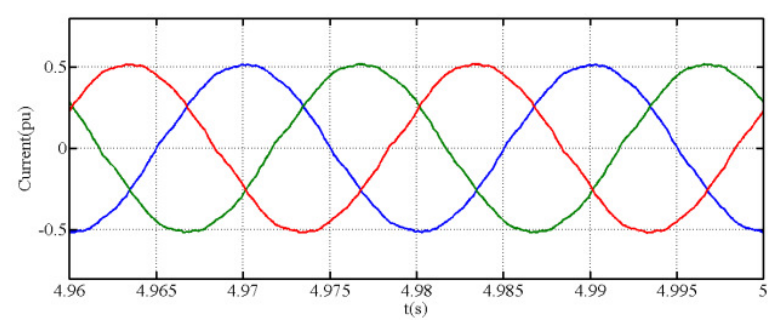

c) Current waveforms converter injects into PCC
To demonstrate the resiliency of the modular multilevel converter based STATCOM to ac network faults, the test network in Fig. $1 \mathrm{~b}$ is subjected to symmetrical and asymmetrical faults at point of common coupling, with $140 \mathrm{~ms}$ fault duration. Fig. 3 displays results for symmetrical threephase fault. Figs. $3 \mathrm{a}$ and $3 \mathrm{~b}$ show voltage magnitude at PCC and reactive power STATCOM exchange with PCC. These results show that as the voltage magnitude at PCC collapses to less that 0.2 per unit, STATCOM autonomously adjusts its reactive power output to support grid voltage. Figs. $2 \mathrm{c}$ and $2 \mathrm{~d}$ show the voltage waveforms at PCC and current waveforms STATCOM contributes to the ac network. It can be observed that despite the voltage collapse at PCC, STATCOM injected limited current into ac network at PCC, hence there is no risk of devices failure from increased current stress, thanks to STATCOM current controller. Fig. 3e shows the cell capacitor voltages are maintained under control despite the voltage dip at the STATCOM ac side; this also demonstrates that there is no risk of devices failure due to increased voltage stresses.

The case for asymmetrical faults is presented in Fig. 4, when the network in Fig. 1b is subjected to single-phase to ground fault. Figs. $4 \mathrm{a}$ and $4 \mathrm{~b}$ show voltage waveform at PCC, and active and reactive power STATCOM exchanges with the ac network. It can be observed that STATCOM adjusts its reactive power exchange with $\mathrm{PCC}$ in order to support the ac voltage. Compared to the three-phase fault case, STATCOM is able to inject significant reactive power into PCC during single-phase case without significant increase in device current stresses as shown in Fig. 4c. This because its ability to produce reactive power reduces with the reduction in ac voltage magnitude at PCC in the case of three-phase fault, and forces current control to saturate.

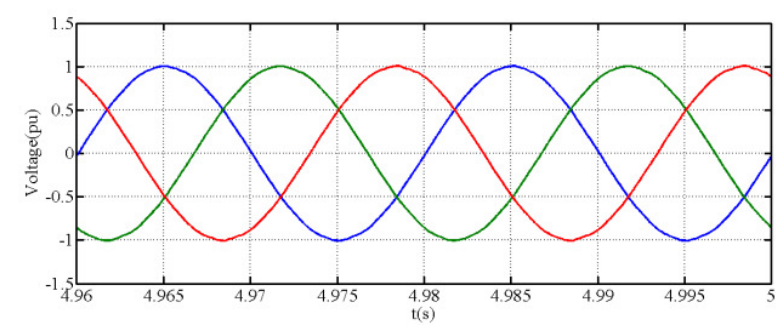

b) Voltage waveform at PCC

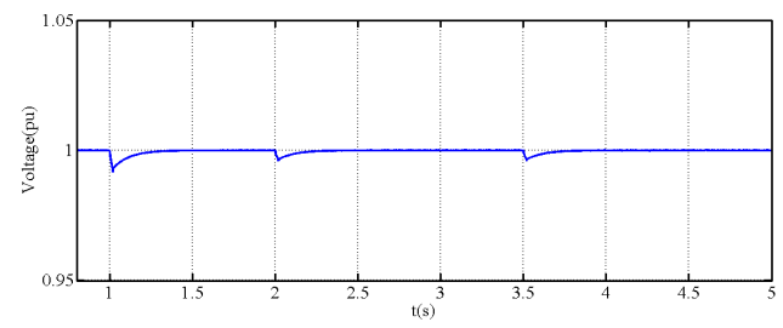

d) Voltage magnitude at PCC 


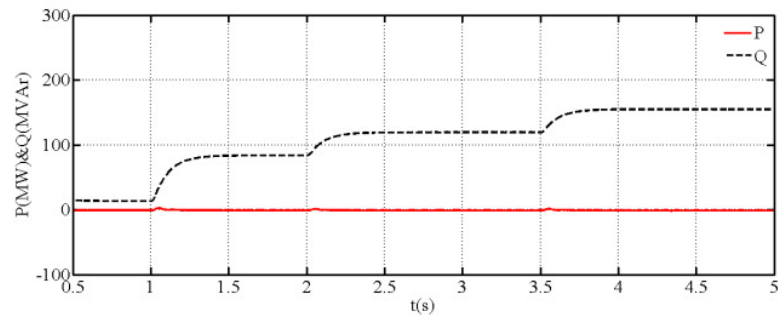

e) Active and reactive power converter exchanges with PCC

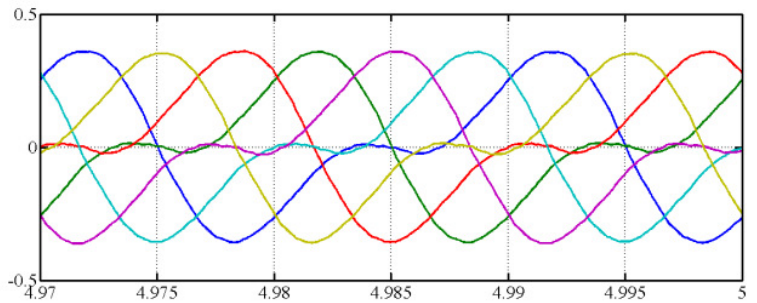

f) Current waveforms in six converter arms

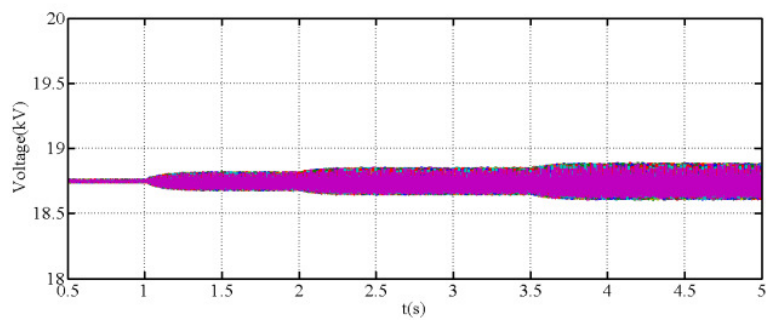

g) Voltage across 96 cell capacitors of the three phases

Waveforms demonstrating the dynamic performance of STATCOM based modular converter when providing voltage support at transmission level

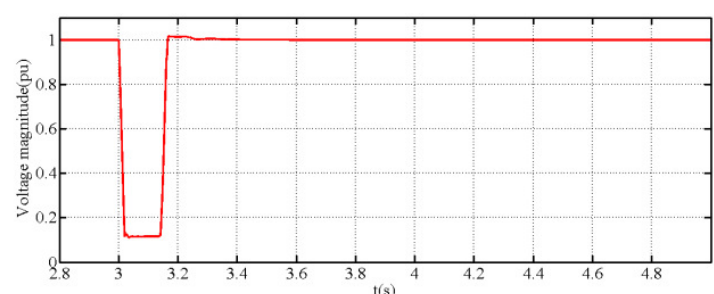

a) Voltage magnitude at PCC

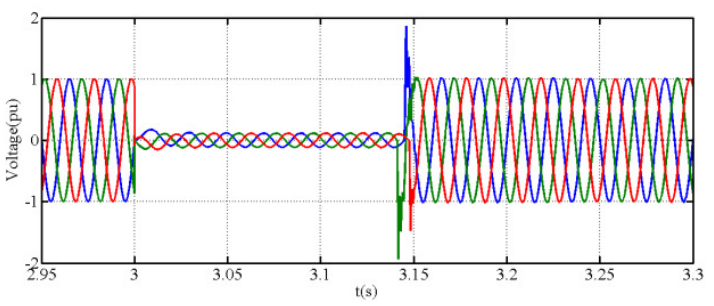

c) Voltage waveform at PCC

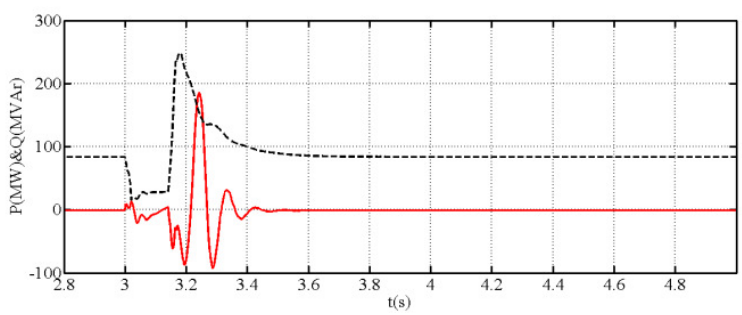

b) Active and reactive power converter exchanges with PCC

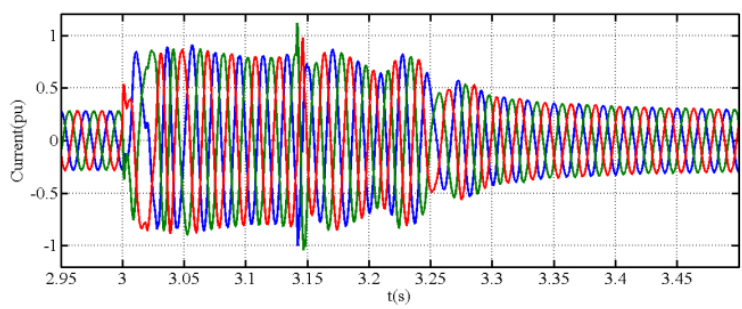

d) Current waveforms converter injects into PCC

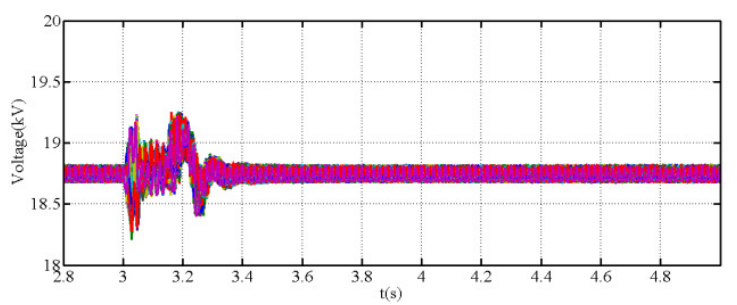

e) Voltage across 96 cell capacitors of the three phases

Fig. 3: Waveforms demonstrating the fault ride capability of STATCOM based on modular converter (symmetrical three-phase fault) 


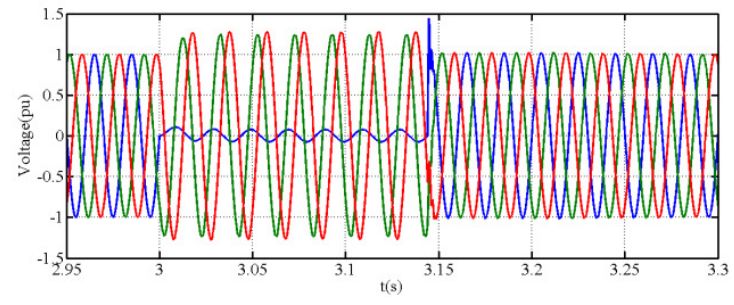

a) Voltage waveforms at PCC

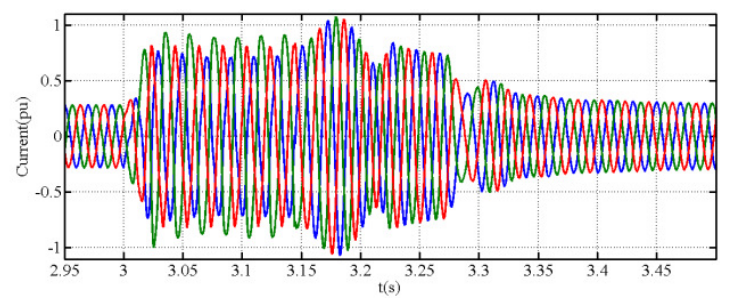

c) Current waveforms converter injects into PCC

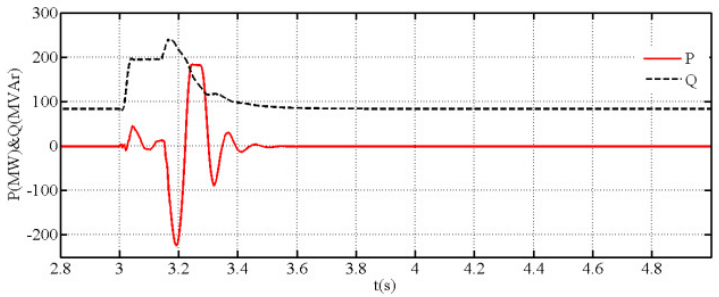

b) Active and reactive power converter exchanges with PCC

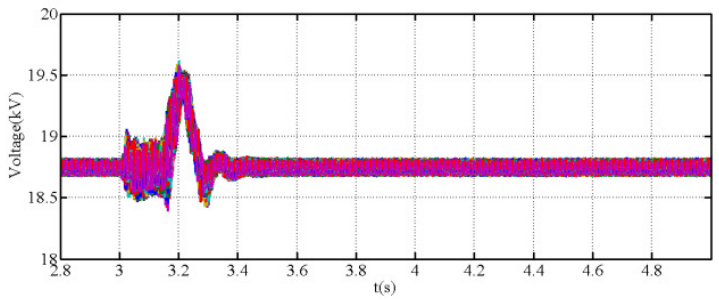

d) Voltage across the 96 cell capacitors of the three phase

Fig. 5: Waveforms demonstrating fault ride-through capability of STATCOM based modular converter (asymmetrical fault, single-phase fault)

\section{Conclusions}

This paper investigated the steady-state and transient response of the static synchronous shunt compensator based on modular multilevel converter when connected to transmission level. It has been shown that the use of modular converter based STATCOM may be beneficial from both system and device point of view in terms resiliency to ac network faults; the use of distributed capacitors instead of common dc link capacitor eliminates the risk of dc side fault. absence of $\mathrm{dc}$ offsets in converter arm currents may reduce STATCOM conversion losses; and suitable for transformer and transformerless applications.

\section{References}

[1] X. Zhengping, et al., "Improving distribution system performance with integrated STATCOM and supercapacitor energy storage system," in Power Electronics Specialists Conference, 2008. PESC 2008. IEEE, 2008, pp. 1390-1395.

[2] L. Kuang, et al., "Strategies and Operating Point Optimization of STATCOM Control for Voltage Unbalance Mitigation in Three-Phase Three-Wire Systems," Power Delivery, IEEE Transactions on, vol. 22, pp. 413-422, 2007.

[3] H. Chong, et al., "STATCOM Impact Study on the Integration of a Large Wind Farm into a Weak Loop Power System," in Power Systems Conference and Exposition, 2006. PSCE '06. 2006 IEEE PES, 2006, pp. 1266-1272.
[4] G. P. Adam, et al., "Transformerless STATCOM based on a five-level modular multilevel converter," in Power Electronics and Applications, 2009. EPE '09. 13th European Conference on, 2009, pp. 1-10.

[5] H. P. Mohammadi and M. T. Bina, "A Transformerless MediumVoltage STATCOM Topology Based on Extended Modular Multilevel Converters," Power Electronics, IEEE Transactions on, vol. 26, pp. 1534-1545, 2011.

[6] H. Akagi, et al., "A 6.6-kV Transformerless STATCOM Based on a Five-Level Diode-Clamped PWM Converter: System Design and Experimentation of a 200-V 10-kVA Laboratory Model," Industry Applications, IEEE Transactions on, vol. 44, pp. 672-680, 2008.

[7] M. Saeedifard, et al., "A Space Vector Modulated STATCOM Based on a Three-Level Neutral Point Clamped Converter," Power Delivery, IEEE Transactions on, vol. 22, pp. 1029-1039, 2007.

[8] A. de la Villa Jaen, et al., "Voltage Source Converter Modeling for Power System State Estimation: STATCOM and VSC-HVDC," Power Systems, IEEE Transactions on, vol. 23, pp. 1552-1559, 2008.

[9] G. P. Adam, et al., "Modular multilevel inverter: Pulse width modulation and capacitor balancing technique," Power Electronics, IET, vol. 3, pp. 702-715, 2010.

[10] B. N. Alajmi, et al., "Modular multilevel inverter with maximum power point tracking for grid connected photovoltaic application," in Industrial Electronics (ISIE), 2011 IEEE International Symposium on, 2011, pp. 2057-2062.

[11] G. P. Adam, et al., "Modular multilevel converter for medium-voltage applications," in Electric Machines \& Drives Conference (IEMDC), 2011 IEEE International, 2011, pp. 1013-1018. 